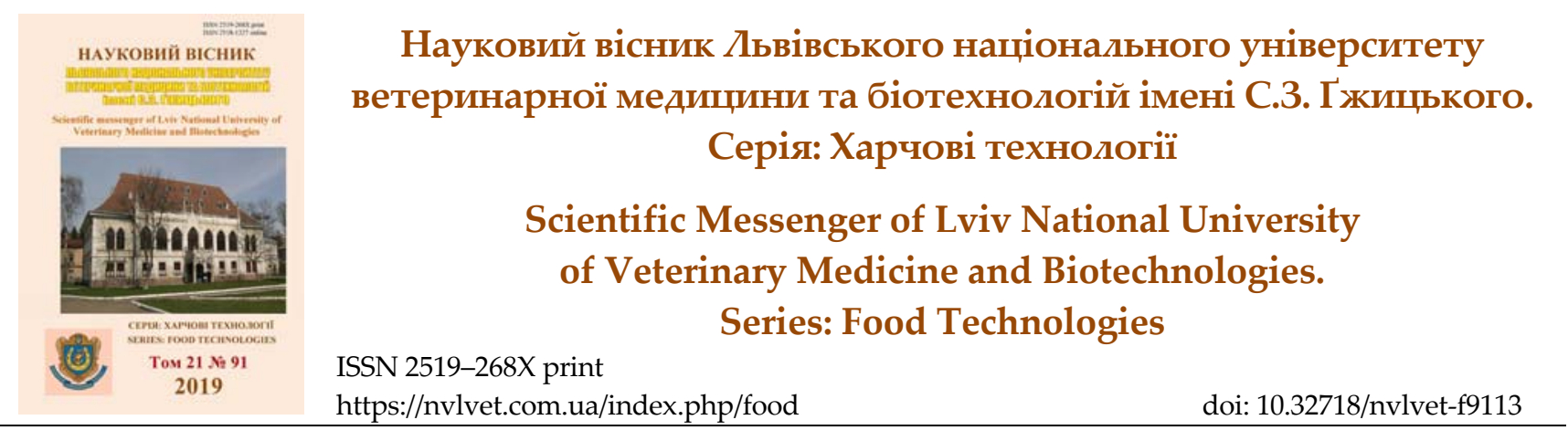

UDC 637.1

\title{
Sour milk product with high protein content
}

\author{
V. Rudiuk, V. Pasichnyi, T. Khorunzha, O. Krasulya \\ National University of Food Technologies, Kyiv, Ukraine
}

Article info

Received 25.01.2019 Received in revised form 25.02.2019 Accepted 26.02.2019

National University of Food Technologies, Volodymyrska Str., 68 Kyiv, 01033, Ukraine. Tel.: +38-068-047-49-23 E-mail:witalka_net@ukr.net

\begin{abstract}
Rudiuk, V., Pasichnyi, V., Khorunzha, T., \& Krasulya, O. (2019). Sour milk product with high protein content. Scientific Messenger of Lviv National University of Veterinary Medicine and Biotechnologies. Series: Food Technologies, 21(91), 79-83. doi: 10.32718/nvlvet-f9113
\end{abstract}

The formulations of sour-milk products made by the thermostat method with the use of protein concentrates are developed. The classic technology of thermosetting is used as a basis, with preliminary preparation of mixtures based on normalized milk, milk protein concentrate (KMBS-65) and serum protein ultra filtration concentrate (KSB-UV-65), followed by pasteurization and suction. Concentrates used in dry form. Milk protein promotes nutrition of tissues not short-lived, but in the long-term, which is very important for intense physical activity, and high intellectual activity. Whey protein is rapidly absorbed and the nutrients that it carries with them, in short time, enter the tissues of the body, including muscle. This allows you to compensate for energy costs in a short time and improve the processes of exchange designed to normalize the work of organs and systems. Protein concentrates are used to improve the density of the bunch and reduce the degree of syneresis. The product is enriched with a concentrate and will act as an additional source of natural milk protein supplementation to the human body. The optimum component composition of the mixture - the sour milk product, using model milk samples and protein concentrates containing 3; 5; 7; $10 \%$ of total volume. Control sample, without protein concentrate. In the preparation of mixtures, the optimal temperature for the administration of protein concentrates was determined by a practical method. Experimental studies were carried out at the research laboratories of the National University of Food Technologies. The comparative characteristics of the physical and chemical characteristics (pH, titrated acidity, protein content) and organoleptic (appearance, color, consistency) of the indices in samples with different percentages of the introduced protein concentrates, with each other and with the control sample were performed. The changes of the indicators of the product during storage within 7 days.

Key words: Concentrate, sour milk product, whey, milk, milk protein.

\section{Кисломолочний продукт 3 підвищеним вмістом білка}

\author{
В.П. Рудюк, В.М. Пасічний, Т.О. Хорунжа, О.О. Красуля
}

Національний університет харчових технологій, м. Київ, Украӥна

\footnotetext{
Розроблено рецептури кисломолочних продуктів, виготовлених термостатним способом з використанням білкових концентратів. За основу взято класичну технологію виготовлення термостатним способом, з попереднім приготуванням сумішей на основі нормалізованого молока, концентрату молочного білкового (КМБС-65) та концентрату сироваткового білкового ультрафільтращійного (КСБ-УФ-65), з подальшою пастеризацією та сквашуванням. Використовувались білкові концентрати в сухому вигляді. Молочний білок сприяє живленню тканин не короткостроковому, а в довготривалому періоді, що дуже важливо при інтенсивних фізичних навантаженнях та високій інтелектуальної активності. Сироватковий білок швидко засвоюється, $і$ поживні речовини, що він несе з собою, в короткі терміни надходять у тканини організму, в тому числі в м'язи. Це дозволяє в короткі терміни компенсувати енергетичні витрати і поліпшити процеси обміну, покликані нормалізувати роботу органів $і$ систем. Білкові концентрати використовуються з метою поліпшення щільності згустку та зниження ступеня синерезису. Продукт, збагачений концентратом, виступатиме додатковим джерелом надходження природного харчового молочного білка до організму людини. Визначено оптимальний компонентний склад суміші - кисломолочного продукту з використанням модельних зразків молока та білкових концентратів із вмістом 3; 5; 7; $10 \%$ від загального обсягу. Контрольний зразок без білкового концентрату. При приготуванні сумішей практичними методом визначено оптимальну температуру для внесення білкових концентратів. Експериментальні дослідження виконувались у науково-дослідних лабораторіях Наџіонального університету харчових технологій. Проведено
} 
порівняльну характеристику фізико-хімічних (рН, титрована кислотність, вміст білка) та органолептичних (зовнішній вигляд, колір, консистенцію) показників у зразках з різним відсотковим значенням внесених білкових концентратів між собою та із контрольним зразком. Досліджено зміни показників продукту під час зберігання протягом 7 діб.

Ключові слова: концентрат, кисломолочний продукт, сироватка, молоко, молочний білок.

\section{Вступ}

На даний час на ринку харчових продуктів все більшої популярності набуває дієтичне та спортивне харчування.

3-поміж усіх продуктів, зосереджених на цих напрямках, свій осередок сформували і молочні продукти, зокрема кисломолочні напої. Збалансований якісний склад продукту забезпечить організму надходження життєво важливими нутрієнтами, а від цього залежать такі важливі біологічні характеристики організму як інтенсивність росту, будова тіла, особливості обміну речовин, стан імунної системи, захворюваність і тривалість активного життя (Yehorov, 2011; Prazeres et al., 2012; Gun'kova \& Gorbatova, 2015; Nagovska et al., 2018).

Актуальним є введення до рецептур кисломолочних напоїв окремих видів фізіологічнофункціональних інгредієнтів в кількостях, що забезпечать 3 порцією продукту вживання 10-50\% рекомендованого рівня адекватного вживання для цього інгредієнта (Rogov et al., 2000; Hinkova et al., 2012; Baccouche et al., 2013). Така модифікація традиційного складу орієнтована на надання продукту властивостей, пов'язаних 3 позитивним ефектом на фізіологічні функції і процесом обміну речовин в організмі людини при систематичному вживанні в складі звичайного раціону.

Актуальність теми. Збагачення кисломолочних напоїв білковими концентратами значно збільшить надходження природного молочного білка до організму людини. Білки молока володіють ліпотропними властивостями, регулюючи жировий обмін, підвищують збалансованість їжі і засвоєння інших білків. Володіючи амфотерними властивостями, молочний білок захищає організм від отруйних речовин (Trukhachev et al., 2009; Yemelin et al., 2009).

Метою роботи є наукове обгрунтування способів внесення білкових концентратів для виготовлення кисломолочних напоїв.

\section{Матеріал і методи досліджень}

Удосконалення технології кисломолочних напоїв 3 підвищеним вмістом білка проводились 3 використанням хімічних, органолептичних, фізико-хімічних, технологічних, мікробіологічних, мікроструктурних методів аналізу. Під час дослідів використовувались стандартні та загальновідомі методи дослідження, що забезпечують виконання поставлених завдань.

\section{Результати та їх обговорення}

В процесі досліджень визначали оптимальний компонентний склад суміші - основи кисломолочного напою 3 використанням модельних зразків суміші молока та білкових концентратів в кількості $3 ; 5 ; 7$; $10 \%$ від загального обсягу суміші. Контрольним був зразок без білкового концентрату.

Виробництво кисломолочних напоїв проводили згідно з класичною технологією термостатним способом. Для приготування суміші використовували молоко (масова частка жиру $3,2 \%$, масова частка сухих речовин $-8,5 \%$; лактози $-4,7 \%$; білка $-3,0 \%$; щіль-

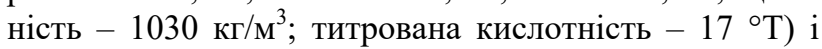
концентрати білків “КСБ -УФ- 65" та "КМБС -65”. У підготовлені суміші вносили закваску VIVO "Віталакт" (Streptococcus thermophilus, Lactobacillus delbrueckii ssp. bulgaricus, Lactobacillus acidophilus, Bifidobacterium lactis, Lactococcus lactis ssp. Cremoris, Lactococcus lactis ssp. Lactis, Lactococcus lactis ssp. lactis var. diacetylactis, Streptococcus thermophilus, Мікрофлора кефирних зерен, Lc. Lactis, Streptococcus thermophilus, Lactobacillus ssp., Kefir yeast) (ТУ 9229166-00419785-99).

Сквашування проводили при температурі $(40 \pm 2)^{\circ}$ С протягом 6-8 год до наростання титрованої кислотності $(90 \pm 2)^{\circ} \mathrm{T}$.

3 метою інактивації сторонньої мікрофлори застосовували пастеризацію при температурі $(85 \pm 2){ }^{\circ} \mathrm{C}$ без витримки. Деякі досліджувані зразки володіли слабкою термостійкістю, зокрема зразки з КСБ-УФ-65 (7\% та 10\%) при термічній обробці білки денатурували 3 утворенням великих пластівців. Це пов'язано зі збільшенням кількості сироваткових білків, особливо термолабільного Р-лактоглобуліну, і зміною сольової рівноваги системи за рахунок мінеральних речовин, внесених в КСБ-УФ-65. Тому ці зразки пастеризувалися при $72 \pm 2$ з витримкою 25-30 с.

Розроблено модельні рецептури 3 використанням Концентрату сироваткового білкового "КСБ -УФ-65" (ТУ У 15.5-35293993-002:2011) та Концентрату молочного білкового сухого "КМБС-65" (ТУ У 10.5 35293993-021:2016). Модельні рецептури кисломолочних продуктів 3 використанням концентрату сироваткового білкового “КСБ-УФ-65” в таблиці 1.

\section{Таблиця 1}

Модельні рецептури кисломолочних продуктів з використанням КСБ-УФ-65 та КМБС-65

\begin{tabular}{lcccc}
\hline \multicolumn{1}{c}{ Складові рецептури } & \multicolumn{4}{c}{ Вміст у рецептурі, \% } \\
\cline { 2 - 5 } & Рецептура 1 & Рецептура 2 & Рецептура 3 & Рецептура 4 \\
\hline Молоко пастеризоване 3,2\% & 97 & 95 & 93 & 90 \\
КСБ-УФ-65 або КМБС-65 & 3 & 5 & 7 & 10 \\
Всього & 100 & 100 & 100 & 100 \\
\hline
\end{tabular}


Після утворення сумішей досліджуваних зразків було визначено титровану кислотність, $\mathrm{pH}$, вміст сухих речовин та вміст білка перед сквашуванням. Залежність титрованої кислотності в суміші щодо кількості та виду білкового концентрату наведено на рис. 1.

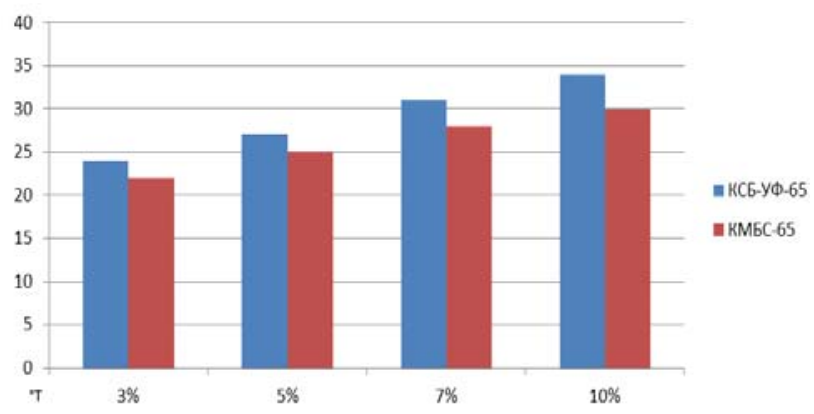

Рис.1. Залежність титрованої кислотності в суміші щодо кількості та виду білкового концентрату

Контрольний зразок мав кислотність на рівні $18^{\circ} \mathrm{T}$. На цьому етапі можна спостерігати, що вміст у сумішах білкових концентратів впливає на титровану кислотність, підвищуючи іï при концентрації 10\% у випадку із використанням КМБС-65 досягає значення $30^{\circ} \mathrm{T}$, та $34^{\circ} \mathrm{T}$ із КСБ -УФ-65 відповідно.

Значення $\mathrm{pH}$ досліджуваних зразків наведено на рис 2.

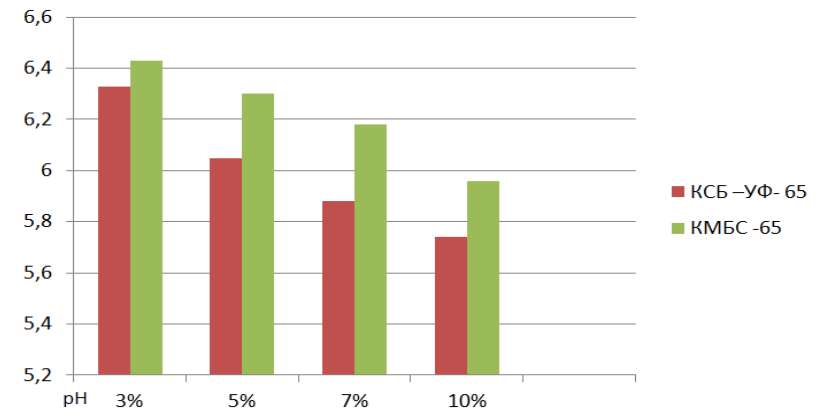

Рис. 2. Залежність рН суміші від кількості та виду білкового концентрату

Контрольний зразок - pH 6,67. На гістограмі видно, що значення рН зменшується пропорційно збільшенню відсоткового значення білкових концентратів у суміші. Кількість білка у зразках наведено на рис. 3 .

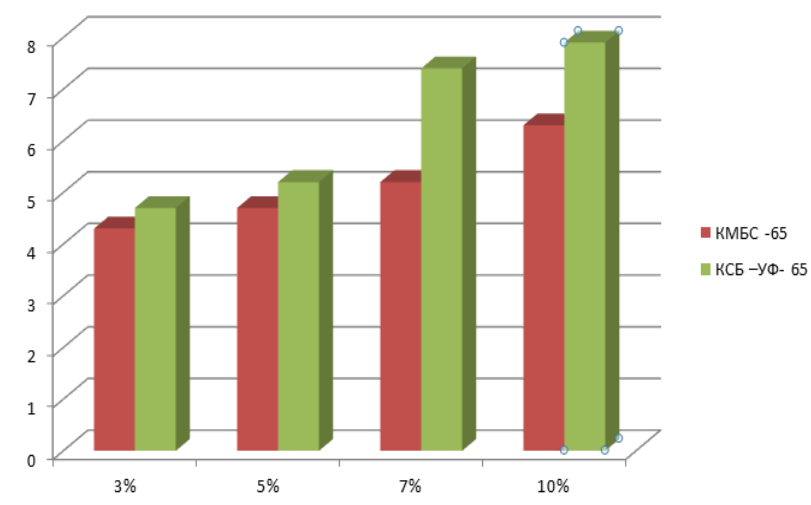

Рис. 3. Вміст білка в дослідних зразках кисломолочного продукту
Контрольний зразок мав значення по вмісту білка на рівні 3,1\%.

Відсоткове значення вмісту білка значно зростає. При додаванні 10\% КСБ-УФ-65 досягає 7,9\%. При внесенні КМБС-65 значення дещо менші, але також, майже у два рази перевищують контрольний зразок. Вже на цьому етапі можна стверджувати, що білкові концентрати можна використовувати як збагачувачі білкового складу у молочних продуктах. Відповідно до того, що вміст білка значно виріс, значення СЗМЗ також зростає, що зображено на рис 4.

Вміст сухих речовин наведено на рис.4.

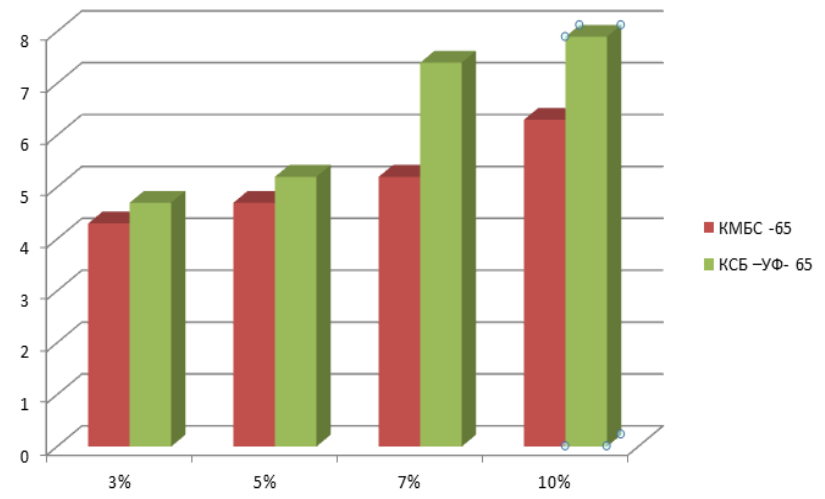

Рис. 4. Вміст сухих речовин в дослідних зразках кисломолочного продукту

Після завершення сквашування зразки було охолоджено до $20^{\circ} \mathrm{C}$ та проведено визначення органолептичних показників і значень $\mathrm{pH}$ і титрованої кислотності. Органолептичні властивості дослідних зразків 3 використанням КСБ-УФ-65 та КМБС-65 наведено в табл. 3. та табл. 4.

Для кращого дослідження розроблених зразків була проведена дегустаційна оцінка органолептичних показників.

За результатами органолептичної оцінки (консистенція, смак та запах) досліджувані зразки з КМБС-65 та КСБ-УФ-65 ( концентрацією 3\% та 5\%) не сильно відрізняюється від контрольного зразка. При додаванні КМБС-65 у кількості 7\% та 10\% консистенція ставала значно пружнішою, згусток дуже щільний. Смак та замах мав певну кислуватість, вищу, ніж у контрольному зразку. При додаванні КСБ-УФ-65 (7\% та 10\%) відчувалась значна борошнистість. Смак та аромат були кислими.

За результатами зведеної дегустаційної оцінки органолептичних показників якості найвищу загальну балову оцінку з урахуванням коефіцієнтів вагомості отримав зразок $з$ додаванням КМБС-65 у кількості $7 \%,(24,88$ бала) і з 5\% (24,60 балів). Загалом, як i було визначено вище, найкращі показники якості із внесеним КМБС-65 мають зразки із 5\% та 7\% внесеного концентрату. 
Таблиця 2

Органолептичні властивості дослідних зразків з використанням

\begin{tabular}{|c|c|c|c|c|}
\hline \multirow{2}{*}{ Назва показника } & \multicolumn{4}{|c|}{ Досліджуваний зразок з різною часткою КМБС-65 } \\
\hline & $3 \%$ & $5 \%$ & $7 \%$ & $10 \%$ \\
\hline $\begin{array}{l}\text { Консистенція і } \\
\text { зовнішній вигляд }\end{array}$ & $\begin{array}{c}\text { М'яка, в'язка без видимих } \\
\text { грудочок та вкраплень }\end{array}$ & $\begin{array}{c}\text { М'яка, в'язка без } \\
\text { видимих грудочок та } \\
\text { вкраплень }\end{array}$ & $\begin{array}{l}\text { Пружна, щільна, } \\
\text { Однорідна }\end{array}$ & $\begin{array}{l}\text { Дуже щільна, } \\
\text { однорідна }\end{array}$ \\
\hline Смак та запах & $\begin{array}{c}\text { Кисломолочний, без сто- } \\
\text { ронній присмаків, власти- } \\
\text { вий даному продукту }\end{array}$ & $\begin{array}{l}\text { Кисломолочний, без } \\
\text { сторонній присмаків }\end{array}$ & $\begin{array}{c}\text { Відчутно кислий, без } \\
\text { сторонніх запахів }\end{array}$ & $\begin{array}{c}\text { Кислий, } \\
\text { аромат властивий } \\
\text { даному продукту }\end{array}$ \\
\hline Колір & Білий $з$ кремовим відтінком & $\begin{array}{c}\text { Білий з кремовим } \\
\text { відтінком }\end{array}$ & $\begin{array}{c}\text { Білий } 3 \text { кремовим відтін- } \\
\text { ком }\end{array}$ & $\begin{array}{c}\text { Білий } 3 \text { кремовим } \\
\text { відтінком }\end{array}$ \\
\hline
\end{tabular}

Таблиця 4

Органолептичні властивості дослідних зразків з використанням КСБ-УФ-65

\begin{tabular}{|c|c|c|c|c|}
\hline \multirow{2}{*}{$\begin{array}{c}\text { Назва } \\
\text { показника }\end{array}$} & \multicolumn{4}{|c|}{ Досліджуваний зразок з різною часткою КСБ-УФ-65 } \\
\hline & $3 \%$ & $5 \%$ & $7 \%$ & $10 \%$ \\
\hline $\begin{array}{l}\text { Консистенція } \\
\text { і зовнішній } \\
\text { вигляд }\end{array}$ & $\begin{array}{c}\text { М'яка, в’язка без видимих } \\
\text { грудочок та вкраплень }\end{array}$ & $\begin{array}{c}\text { М'яка, в'язка без } \\
\text { видимих грудочок та } \\
\text { вкраплень }\end{array}$ & $\begin{array}{c}\text { В'язка видимими вкрап- } \\
\text { леннями нерозчиненого } \\
\text { білка }\end{array}$ & $\begin{array}{c}\text { Щільна, з видимими } \\
\text { вкрапленнями нерозчи- } \\
\text { неного білка }\end{array}$ \\
\hline Смак та запах & $\begin{array}{c}\text { Кисломолочний, без сторон- } \\
\text { ній присмаків, властивий } \\
\text { даному продукту }\end{array}$ & $\begin{array}{c}\text { Кисломолочний, без } \\
\text { сторонній } \\
\text { присмаків }\end{array}$ & $\begin{array}{c}\text { Кислий, без сторонніх } \\
\text { запахів, з відчутною } \\
\text { борошнистістю }\end{array}$ & Кислий, борошнистий \\
\hline Колір & $\begin{array}{c}\text { Білий з жовтуватим } \\
\text { відтінком }\end{array}$ & $\begin{array}{c}\text { Білий з жовтуватим } \\
\text { відтінком }\end{array}$ & $\begin{array}{c}\text { Білий з жовтуватим } \\
\text { Відтінком }\end{array}$ & $\begin{array}{c}\text { Білий з жовтуватим } \\
\text { відтінком }\end{array}$ \\
\hline
\end{tabular}

За результатами зведеної дегустаційної оцінки органолептичних показників якості зразків 3 внесеним КСБ-УФ-65 найвищу загальну балову оцінку з урахуванням коефіцієнтів вагомості отримав зразок з дода- ванням КСБ-УФ-65 у кількості 5\%, (23,78 бала) і з 3\% (24,50 балів).

Дослідження $\mathrm{pH}$, титрованої кислотності та вміст білка після сквашування продукту представлено в табл. 5.

Таблиця 5

Фізико-хімічні дослідження продукту після сквашування

\begin{tabular}{|c|c|c|c|c|c|c|c|c|c|}
\hline \multirow{3}{*}{ Назва показника } & \multicolumn{9}{|c|}{ Дослідний зразок } \\
\hline & \multirow{2}{*}{$\begin{array}{c}\text { Контрольний } \\
\text { зразок }\end{array}$} & \multicolumn{4}{|c|}{ КМБС-65 } & \multicolumn{4}{|c|}{ КСБ -УФ-65 } \\
\hline & & $3 \%$ & $5 \%$ & $7 \%$ & $10 \%$ & $3 \%$ & $5 \%$ & $7 \%$ & $10 \%$ \\
\hline $\mathrm{pH}$ & 4,81 & 4,76 & 4,55 & 4,22 & 4,2 & 4,78 & 4,4 & 4,19 & 4,1 \\
\hline Титрована кислотність, ${ }^{\circ} \mathrm{T}$ & 87 & 89 & 94 & 102 & 104 & 88 & 90 & 110 & 114 \\
\hline Вміст білка,\% & 3,1 & 4,7 & 5,2 & 7,4 & 7,9 & 4,3 & 4,7 & 5,2 & 6,3 \\
\hline
\end{tabular}

Наведені в таблиці. 5 фізико-хімічні показники продукту після сквашування узгоджуються 3 даними органолептичних показників i вказують на те, що використання в складі заквасочних сумішей КСБ-УФ65 і КМБС-65 доцільно в кількості 5\%.

\section{Висновки}

Розроблено та досліджено модельні зразки кисломолочних продуктів з використанням білкових концентратів. Проведено органолептичні оцінки, за якими встановлено оптимальний вміст внесених концентратів. Визначено основні фізико-хімічні показники. За даними результатами можна стверджувати, що внесення КСБ-УФ-65 та КМБС-65 у кількості 5\% буде оптимальною для виготовлення кисломолочних продуктів, збагачених молочним білком.

В подальшому дослідження будуть спрямовані на визначення в'язкості. Також буде досліджено ступінь синерезису після сквашування та протягом терміну зберігання.

\section{References}

Baccouche, A., Ennouri, M., Felfoul, I., \& Attia, H. (2013). Food Hydrocolloids, (33)2, 234-244. doi: 10.1016/j.foodhyd.2013.03.007.

Gun'kova, P.I., \& Gorbatova, K.K (2015). Biotekhnologicheskiye svoystva belkov moloka. SPb: GIORD (in Russian).

Hinkova, A., Zidova, P., Pour, V. Bubnik, Z., Henke, S., Salova, A., \& Kadlec, P. (2012). Potential of Membrane Separation Processes in Cheese Whey Fractionation and Separation. Procedia Engineering, 42, 1425-1436. doi: 10.1016/j.proeng.2012.07.536.

Nagovska, V., Hachak, Y., Gutyj, B., Bilyk, O., Slyvka, N. (2018). Influence of wheat bran on quality indicators of a sour milk beverage. Eastern-European Jour- 
nal of Enterprise Technologies, 4, 11(94), 28-35. doi: 10.15587/1729-4061.2018.140093.

Nagovska, V.O., Hachak, Yu.R., Bilyk, O.Ya., Gutyj, B.V., Slyvka, N.B., \& Mikhailytska, O.R. (2018). Influence of thistle grist on organoleptic, physicochemical and microbiological parameters of kefir. Scientific Messenger of Lviv National University of Veterinary Medicine and Biotechnologies, 20(85), 166170. doi: 10.15421/nvlvet8530.

Prazeres, A.R., Carvalho, F., \& Rivas, J. (2012). Cheese whey management: Journal of Environmental Management, 110, 48-68. doi: 10.1016/j.jenvman.2012.05.018.

Rogov, I.A., Antipova, L.V., Dunchenko, N.I., \& Zherebtsov, N.A. (2000). Khimiya pishchi: Belki: struktura, funktsii, rol' $\mathrm{v}$ pitanii. M. Kolos (in Russian).

Trukhachev, V.I., Molochnikov, V.V., Orlova, T.A., \& Ramanauskas, R.I. (2009). Kontsentraty belkov moloka. Stavropol'. AGRUS (in Russian).

Yehorov, B. (2011). Formuvannya kharchovykh ratsioniv naselennya. M. Mardar Tovary i rynky. 1, 140-147 (in Ukrainian).

Yemelin, V.P., Bokarev, A.V., \& Trifanov, I.YU. (2009). Sostav i svoystva molochno-belkovykh kontsentratov, poluchennykh raznymi sposobami. Tekhnika i tekhnologiya pishchevykh proizvodstv, 4, 35-39 (in Russian). 